\title{
LATE CENOZOIC DEPOSITIONS PALEOENVIRONMENTS OF SOUTHEAST FLORIDA INTERPRETED FROM CORE LOGS
}

\author{
LUCIANA S. ESTEVES* \& CHARLES W. FINKL Jnr.**
}

\begin{abstract}
RESUMO PALEOAMBffiNTES DEPOSICIONAIS DO SUDESTE DA FLORIDA, USA, INTEPRETADOS A PARTIR DE LOGS DE TESTEMUNHOS A utilização de testemunhos de sondagem para fins hidrologicos, geologicos ou de engenharia possibilitaram melhor determinar a distabuifao espacial de paleoambientes deposicionais ao longo da costa sudeste da Flórida, onde a estreita plataforma continental foi influenciada por mudangas do nivel do mar e da posição da linha de costa durante o Neo-Cenozoico. Os depositos sedimentares do sudoeste da Florida consistem na Formação Tamiami (Pliocene inferior), Formação Fort Thompson (Plioceno superior), Formação Anastasia (Plioceno-Pleistoceno), Miami Limestone (Pleistocene superior) e areias Pamlico (Pleistocene). A ausencia de afloramentos, a escassez de microf6sseis bioestratigraficamente importantes, a similaridade dos depósitos sedimentares e a intensa diagenese de sefoes fossiliferas tern dificultado o consenso nas interpretações das seções estratigráficas do final do Cenozoico. A inspeção de aproximadamente 18.300 m de dados de sondagens nao publicados, combinada a secoes cruzadas da area de estudo (condado de Broward, Florida), permitiu o mapeamento das redoes verticais e horizontais entre os depdsitos do Miocene, Mioceno-Plioceno, Pleistocene inferior e Pleistocene superior-Holoceno. As interpretafoes litoestratigráficas das mudanças paleoambientais formam a base de um modelo preliminar da geologia costeira do condado de Broward. Este estudo confirma a tendencia geral das mudanfas nas condifoes deposicionais no Cenozdico superior de ambiente marinho (Formafao Tamiami) para marinho raso (Formafao Anastasia e Fort Thompson) a muito raso (fades ooliticas do Miami Limestone) e dep6sitos edlicos da parte superior das areias Pamlico. As tendencias do Pleistocene superior ao Recente mostram um padrao deposicional paralelo a costa formada por baixios (ou Unas barreiras) cortados por antigos braces de mar. Descontinuidades erosivas (interpretadas como superficies caisticas irregulares) observadas nas seções são frequentemente caracterizadas por densas crostas de calcita formadas por intemperismo suba6reo que agem como barreiras semi-permeaveis para o fluxo de àgua subterranea. Conhecer a estrutura geoldgica desta àrea é importante para melhor compreender as descargas de água subterranea em ambiente marinho, os tipos de intrusoes de agua salgada e as condições limites para os modelos de fluxo subterraneo, consequentemente tem implicações práticas na otimização do gerenciamento dos recursos hidricos ao longo da costa sudeste da Florida.
\end{abstract}

Palavms-chaves: flutuações do nível do mar, geologia costeira, carbonatos, correlação espaciaJ, Quaternário, Terciário

ABSTRACT The use of core logs from water wells and engineering-geological site investigations permitted spatial refinement of known paleodepositional environments along the southeastern coast of Florida where the narrow continental shelf was influenced by changes in sea level and shoreline position during the late Cenozoic. Lithological materials have been formalized in terms of the Tamiami Formation (early Pliocene), Fort Thompson Formation (late Pliocene), Anastasia Formation (Pliocene-Pleistocene), Miami Limestone (late Pleistocene), and Pamlico sands (Pleistocene) in southeastern Florida. The lack of good exposures, scarcity of biostratigraphically important microfossils, similarity of sedimentary deposits, and pervasive diagenesis of fossiliferous sections have mitigated against a consensus of interpretation for late Cenozoic stratigraphic sections. Inspection of more than $18,300 \mathrm{~m}$ of unpublished core log data combined into cross-sections that crisscrossed the Broward County study area, permitted mapping of vertical and horizontal relationships for Miocene, Miocene-Pliocene, early Pleistocene, and late Pleistocene/Holocene time frames. These lithostratigraphic interpretations of changing paleoenvironments formed the basis of a preliminary model for the coastal geological framework of Broward County. This study confirmed general late Cenozoic trends in sedimentation from marine conditions (Tamiami Formation) to nearshore (Anastasia Formation, Fort Thompson Formation) settings to very shallow marine environments (oolitic facies of the Miami Limestone) and eolian materials in the upper Pamlico sands. Late Pleistocene to Recent trends showed a shore-parallel pattern of shallow paleobathymetries that included barrier bars and tidal passes (paleoinlets). Erosional unconformities (interpreted as irregular karstified groundsurfaces with low paleotopographic relief) in the sections were frequently capped by dense subaerial weathering crusts of calcite which today act as semi-impermeable barriers to groundwater flow. Knowledge of this coastal geological framework is relevant to increased understanding of submarine groundwater discharges, modes of saltwater intrusion, boundary conditions for groundwater models, and has practical implications for optimized water management along the southeast coast of Florida.

Keywords: sea-level change, coastal geology, carbonates, spatial correlation, Quaternary, Tertiary

INTRODUCTION Certain aspects of the late Cenozoic stratigraphy of southeastern Florida has, in many aspects, always been problematic due to: (1) similarities of the lithologic characteristics of sedimentary deposits of various ages, (2) apparent penecontemporaneous association of different materials in close proximity to each other, (3) lack of good exposures in a landscape of low relief, and (4) scarcity of biostratigraphically important microfossils (Scott 1993). Additional complications in studying the Neogene sections in particular include pervasive diagenesis of microfossils in the fossiliferous sections and of those fossils remaining intact, most are often the long ranging, environmentally tolerant species of little or no biostratigraphic significance (Scott 1993). Much of the stratigraphic knowledge accumulated in southeastern Florida was derived from subsurface investigations utilizing drill cores. Despite the long history of investigation, correlation of these deposits is often difficult because of poor and sporadic exposures combined with a lack of age-diagnostic index taxa (e.g. planktonic micro- and nannofossils) in predominantly shallow-water marine environments (Jones et al. 1993).

Our interest in the subsurface geology of this region stemmed from the need to better understand how the coastal geologic framework affected groundwater flow along the land-sea interface. Of particular concern were seaward boundary conditions of groundwater models that were set at the Intracoastal Waterway (ICWW), modes of saltwater intrusion, and the presence of thin impervious layers (subaerial crusts) that affected solute transport at polluted sites. Finkl et al. (1995) further noted that submarine groundwater discharges along the southeast coast of Florida provided important inputs of nutrient-rich freshwater to an open ocean reef complex. Sedimentary formations and aquifers which extend oceanward from the interior of the Florida Platform are truncated along the narrow continental margin, viz. submarine groundwa- ter discharges from Pamlico sands, Anastasia Formation, and Biscayne Aquifer which seem to correlate with the first, second, and third reefs lying along the 10,20 , and $30 \mathrm{~m}$ isobaths. It was further proposed that the present reef tracts approximate the position of paleo-watertables and springs that formed during times of lowered sea level and that $\mathrm{tW}^{\mathrm{ied}}$ erosion surfaces can be detected in geophysical logs by elevated $\mathrm{U}$ and other radioactive isotopes (Krupa et al. 1995). Delineation of the coastal geological framework, including relationships between surface topographic features, lithology, and hydrology is important to considerations of hydrological properties of surface and groundwater flow (Finkl \& Esteves 1997), viz. infiltration, percolation, flux rates, and direction. Elucidation of lithological and stratigraphic variations thus has clear and practical implications for optimized water management along the southeast coast of Florida.

A primary purpose of this study was to establish the late Tertiary and Quaternary paleoenvironments of sedimentary deposition for the Broward County area (about 2,800 km ) (Fig. 1). Analysis of extensive core log data, coupled with ancillary information, provided an opportunity to better understand the shallow $(<80 \mathrm{~m}$ deep) subsurface features of the region. Analysis of stratigraphic sequences resulted in definition of vertical and lateral variations in sedimentary properties, which in turn provided a base for interpreting depositional environmental conditions. As the different types of sedimentary environments (open and restricted marine settings) were displaced both in time and space with decreasing depth associated with marine regressions, it was possible to broadly identify locations of barrier bar and channel systems (paleoinlets), shallow carbonate banks (shoals), marshes, lagoons, etc. Erosional unconformities in the sequence are often marked by thin $(<0.5 \mathrm{~m})$ but dense subaerial crusts (calcrete, caliche) and calcite cavity infills.

* Fundação Universidade do Rio Grande, Departamento de Geociencias/Laboratorio de Oceanografia Geológica - CP 474,96201-900 Rio Grande - RS, Brasil,

FoneFax: (0532) 336605, e-mail: dgelse@super.furg.br

** Florida Atlantic University, Department of Geography and Geology, P.O. Box 3091, Boca Raton, FL 33431 - USA, e-mail: cfink1@gate.net 
METHODS This project was conducted in two phases that involved firstly the collection of borehole logs and, secondly, the analysis and interpretation of the assembled lithologic information. In this urbanized coastal area, it was suspected that much unpublished information had been collected by a variety of sources (e.g. consulting engineering firms, Florida Department of Transportation, Florida East Coast Railway, Broward County School Board, U.S. Army Corps of Engineers) and that it would be useful to collate the well log data in some organized manner. Approximately $14,000 \mathrm{~m}$ oflithologic information was collected from previously unpublished sources. Collation of published logs accounted for about 4,367 $\mathrm{m}$ of sedimentologic data from Causaras (1985) and Florida Geological Survey reports. Such data were entered into a database that was later re-arranged into 68 lithologic logs in diagrammatic format.

The second phase of the project is summarized by interpretations of depositional environments based on 9 cross-sections that crisscrossed the county. Location oflithologic logs and the position of the cross-sections used in this study are shown in figure 2 .

A simplified representation of three cross-sections (WE1, WE3, and WE4) each comprised by three representative logs from eastern, central, and western Broward are shown in a 3-D diagram to illustrate the main geospatial relationships deduced from this study (Fig. 3). The locations of the logs are geographically correct and elevations adjusted

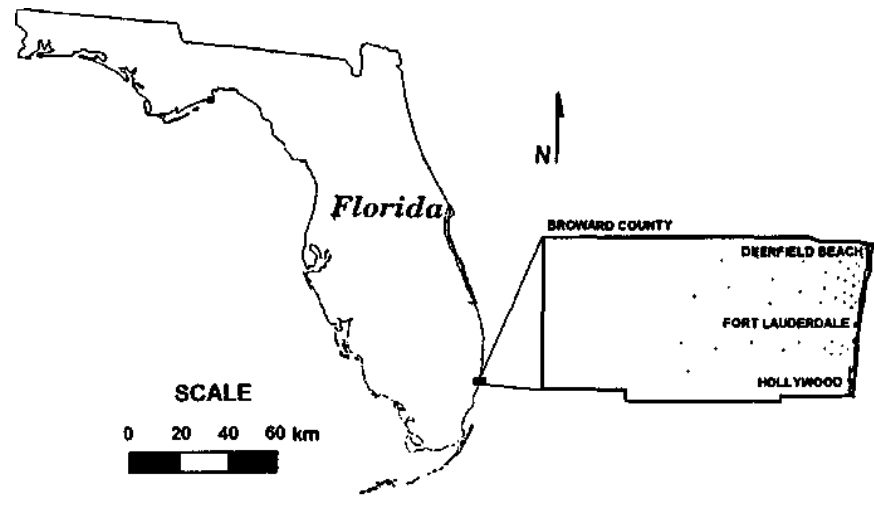

Figure 1 - Location of the Broward County study area along the lower east coast of the Florida peninsula. The study area comprises about $28,000 \mathrm{~km}^{2}$, two-thirds of which is in water conservation areas today. to mean sea level (National Geodetic Vertical Datum (NGVD), 1927). Analysis of the vertical and spatial relationships observed in the cross-sections resulted in four plan-view maps that show the distribution of paleoenvironments during the Miocene (Fig. 4), Miocene-Pliocene (Fig. 5), Early Pleistocene (Fig. 6), and Pleistocene (Fig. 7). The maps and interpretations are regarded as preliminary because they will no doubt be modified as more (unpublished) detailed information is reviewed. Lithologic logs and cross-sections were constructed using RockWorks ${ }^{\circledR}$ software, a specialized geological graphics program.

Interpretations of depositional environments were based on sedimentary properties such as granulometry, rock color, mineralogy, weathering, and fossils as described by Alien (1982) and Collinson \& Thompson (1989). The recognition of freshwater limestones in marine carbonate sequences was based on the work of Halley \& Rose (1977) when appropriated. Evidence of marine deposition was associated with the presence of high content (up to 30\%) of phosphorite and the fossil assemblages (mollusks, barnacles, bryozoans, corals, and echinoid fragments) were compared to lists of the species common to the area as reported by Parker et al. (1955). Unconformities in the sedimentary strata were frequently marked by solution holes in limestone, neomor-phic calcite, and caliche crusts that are widely interpreted as being characteristic of subaerially weathered limestone surfaces (Sweeting 1973). Stratigraphic interpretations logically follow in the development of a preliminary model for the coastal geological framework, the methodology of which is summarized by Krumbein \& Sloss (1963) and by Friedman et al. (1992).

DISTRIBUTION OF PALEOENVIRONMENTS The geological framework of Broward County is dominated by carbonates formed in shallow marine environments (Finkl \& Esteves 1997), as it is long recognized for the Stratigraphic succession in southern Florida (e.g. Parker \& Cooke 1944, Parker et al. 1955, Hoffmeister 1974, Enos \& Perkins 1977). Although the lithology is mostly comprised by limestones and sandy limestones, siliciclastic deposits (e.g. quartzose sands and sandstones) become relatively more important at depth in older sequences and toward the present-day coastline in eastern Broward. This transition from older siliciclastics to carbonates may be a reflection of environmental evolution in an area that changed from: offshore marine deposits (silts, clays, and mixtures) during the early Miocene (Fig. 4), to nearshore carbonatic deposits and inner shelf sands during the MiocenePliocene (Fig. 5), to subaerial and shallower submerged coastal deposits during the Pleistocene (Figs. 6 and 7).

Although there are many uncertainties surrounding the boundary conditions between the sedimentary environments and timing of deposition, the maps showing spatial distributions of sedimentary environments present a plausible interpretation of depositional conditions in the region. The first paleogeographic map (Fig. 4) shows the spatial

8007'30"

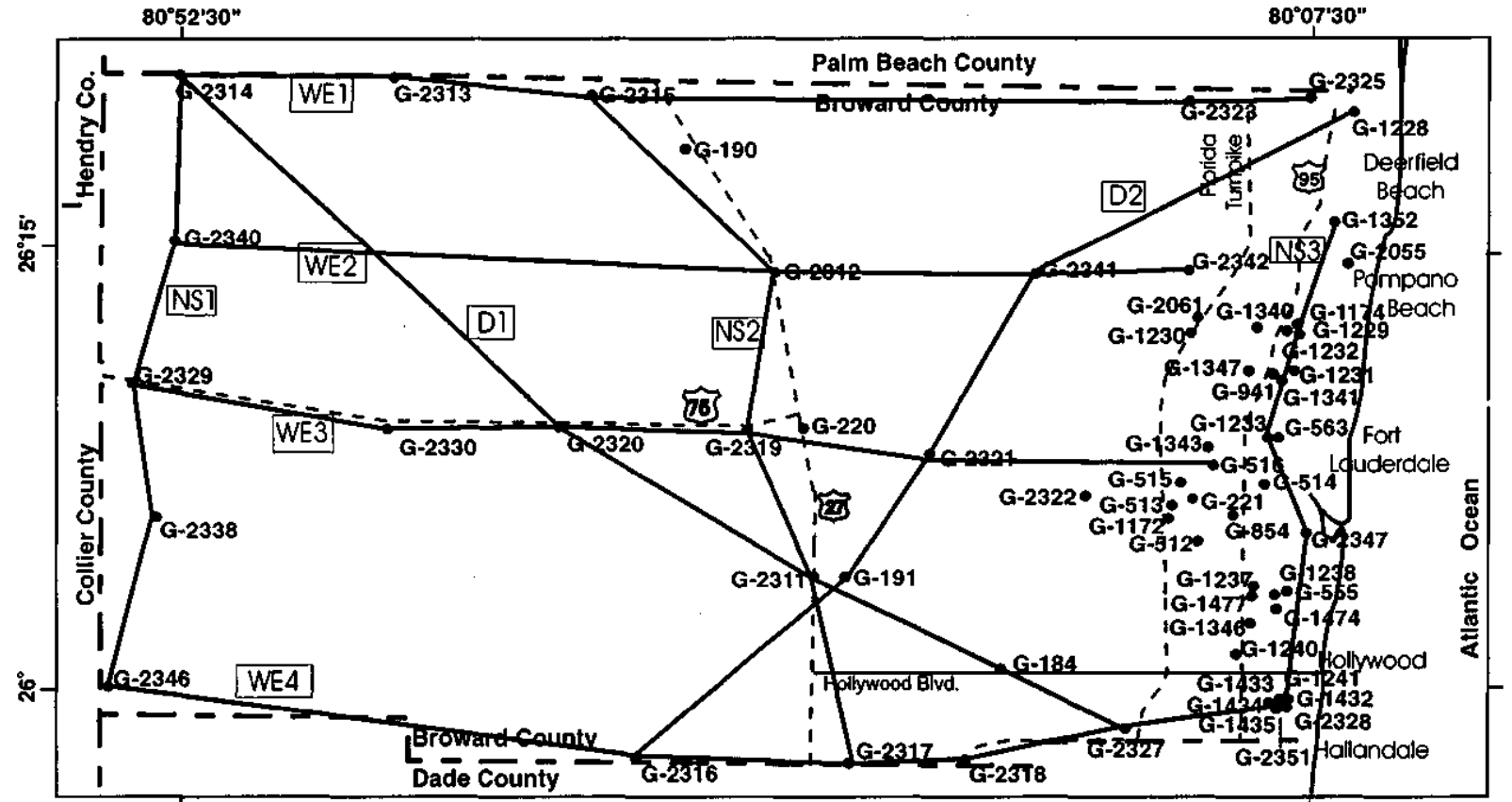

Figure 2 - Map showing location of published lithologic logs and cross-sections that were used as a basis for interpreting depositional conditions and paleogeographic environments in Broward County, Florida. Black dots mark the location of lithologic dots and heavy solid lines represent the crosssections. The bulk of the logs are from the eastern third of the study area where there is extensive urban development. 


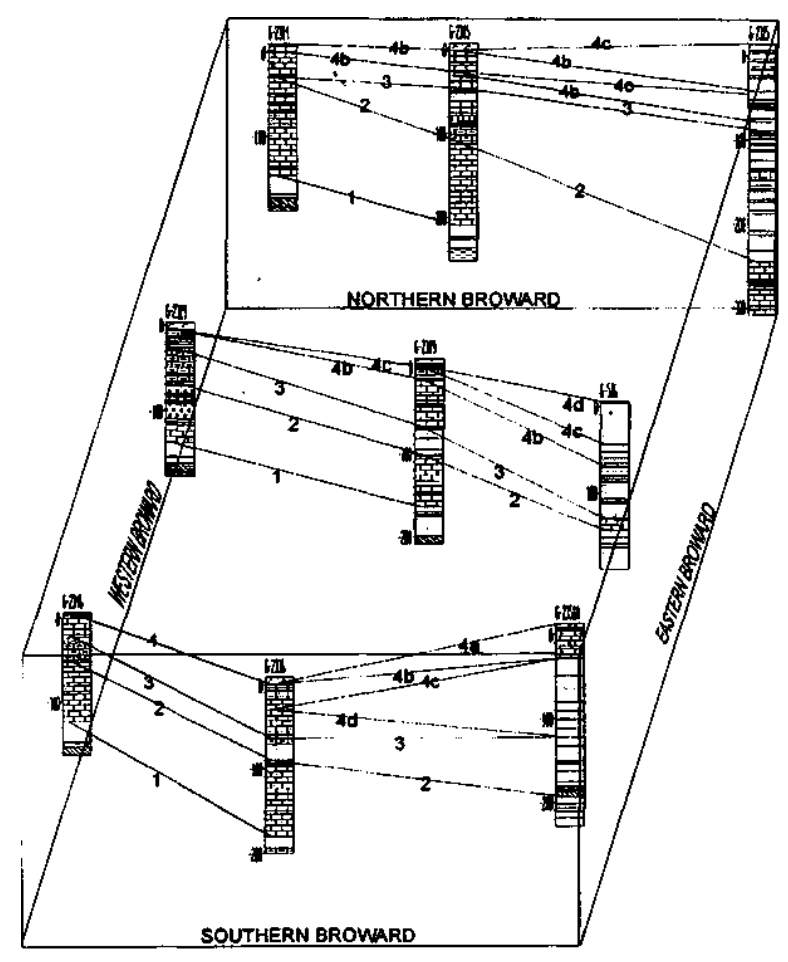

Figure 3 - Tridimensional diagram showing three simplified cross-sections for northern, central, and southern Broward County. Only three representative logs for each cross-section are represented in the diagram although more logs were used in the complete analysis. The setting reference for each borehole was mean sea level according to the NGVD (1927). Because logs elevations are adjusted to NGVD, it is possible to show the relative positions of geological formations that are linked between logs by straight lines. The geographic locations of the logs are georectified to state planar coordinates to facilitate spatial comparisons oflithologic materials. Stratigraphic sequences are indicated in terms of relative chronologies by Arabic numbers from oldest to youngest as follows: (1) lower Pliocene (lower Tamiami Formation), (2) upper Pliocene (upper Tamiami Formation), (3) lower Pleistocene (part of Fort Thompson Formation), and (4) upper Pleistocene. The upper Pleistocene is further subdivided by lithologic composition for (a) Miami Oolite, (b) Fort Thompson Formation, (c) Anastasia Formation, and (d) Pamlico sands.

sediment distribution (in terms of materials that comprise the lower Tamiami Formation) for early Tamiamian time when the study area was submerged as a marine environment. The presence of very fine sediments, such as clays and silts, suggests that the deposition took place under low energy conditions on the outer continental shelf. The second map of late Tamiamian time (Fig. 5) shows the spatial distribution of rather different types of deposits: (1) sandy limestones, (2) fine-grained shelf deposits, and (3) sandy shelf deposits. The rich nearshore fauna in the sandy limestones contains barnacles, coral fragments, pelecypods, echinoid fragments, and sponges, all of which are also associated with quartzose sands and occasional clays or silts in places. The sandy limestones seem to have been deposited in a nearshore environment that was similar to modern conditions because the deposits contain abundant fauna that develops under warm-water conditions. The coarse sands were probably deposited seaward of the reefal area and the fine-grained sediments between the reefs as interreefal deposits. Depositional conditions during the Miocene changed from deep marine to shallower nearshore waters due to a drop in sea level (Peck et al. 1976). Describing a major marine regression at the top of the Tamiami Formation, Webb et al. (1978) suggested a glacioeustatic lowering of sea level as the cause of this regression as well as several minor fluctuations within the formation.

The third paleogeographic reconstruction, for early Pleistocene time (Fig. 6), shows a more complex arrangement of depositional environments due to decreasing water depths. With a falling sea level and prograding shoreline in the early Pleistocene, nearshore sediments were deposited on top of offshore sands in the upper Tamiami Formation and the previous nearshore deposits were in turn buried by freshwater deposits containing limemuds and sand bars. The nearshore deposits are comprised by marine limestones of the Fort Thompson, Anastasia, and Key Largo formations. The large shore-parallel sand bar complex, which was at times subaerially exposed to form a barrier island, contains siliciclastic beds and calcareous sands and shells that probably belong to the Anastasia Formation (Lovejoy 1987). The limemud deposits were formed under low energy conditions with restricted water circulation (protected by the barrier bar or island complex) that favored chemical precipitation of carbonate ooids. Significantly, the freshwater limestones suggest that at this time there was limited and sporadic subaerial exposure of the landsurface and terrestrial deposition in the northwestern part of the area. The freshwater limestones and the limemud deposits may be part of the Fort Thompson Formation.

Steps in the Stratigraphic transition to late Pleistocene and Holocene time (Fig. 7) are complex and largely unknown. Many logs contain a discontinuity (hiatus) and evidence of erosive events (e.g. weathered calcrete surface and cavity-filling calcite in a karstified landscape). By the end of the Pleistocene, the shallow marine and lagoonal deposits shown in Figure 6 gave way to subaerial (terrestrial) deposits. By the last interglacial (Sangamonian time, $130,000 \mathrm{BP}$ ), sand deposits along eastern Broward were beach and bar material and eolianites of the Anastasia Formation (Evans 1987, Lovejoy 1987). The core logs show the presence of a cross-shore tidal channel in the northeastern part of the study area that cuts through a seaward barrier bar of the type described by Evans (1987). Some locations in the western part of the study area contain peat or muck (Fig. 8), probably deposited in wetlands formed by the gradual shoaling and change from a shallowwater restricted marine environment to a subaerial landsurface. Such deposits presented lateral association with terrestrial and freshwater deposits that were widely spread along central axis of Broward. Other areas in the central and western parts of the study zone at this time were exposed subaerially as a landsurface that carried a mantle of peat.

Changes in environmental conditions were conditioned by variations in shoreline position and associated changes in water depth. Thus, variations of sea level were the most important factor in determining depositional characteristics in Broward County. Missimer et al. (1994) conclude that major fluctuations in sea level are recorded as changes in sediment facies and/or significant time gaps across unconformities.

Paleonvironmental change in western Broward Core logs from the western part of the study area show a gradual change in depositional environments from Miocene offshore clays to nearshore sandy limestones, and finally Holocene freshwater limestones at the top of the sequence (Fig. 8). This Stratigraphic succession suggests a regressional event, although unconformities indicate more than one event, as is described by Webb et al. (1978). They identified three major regressions within the Tamiami Formation, one at the base of the formation, another in upper Miocene strata, and a third at the top in rocks of Pliocene age.

The limemud layers in some logs from central-western Broward (e.g. $\log$ G-2346 in Figure 8) seem to represent a gradual change from an open shallow marine environment to one with restricted water circulation that is favorable to the precipitation of the carbonate, as described by Evans (1987). Alternative interpretations associate limemud layers with lakes that formed in depressions after the retreat of the shoreline. The sand and shell layers represent inundation during sea-level rises (Parker et al. 1955). At the top of the Stratigraphic sequence, the logs record limestone or sandy limestone, sometimes with nearshore fauna and/or freshwater characteristics. If these layers are part of the Fort Thompson Formation, some at the unconformable contact were at the groundsurface for a long time. In the central and southern part of the study area, the deposits also show several characteristics that indicate subaerial exposure such as cavity-filling calcite druses.

Changing paleoenvironments in central Broward In the central part of the county, there are complex Stratigraphic sequences containing limemud, sand and shells that lie between the upper and lower layers of sandy limestone in the Fort Thompson Formation (e.g. $\log$ G-2319, Figure 8). This increasing complexity oflithologic pattern suggests that this coastal area was more susceptible to minor changes in sea level while the western and eastern parts were respectively above 


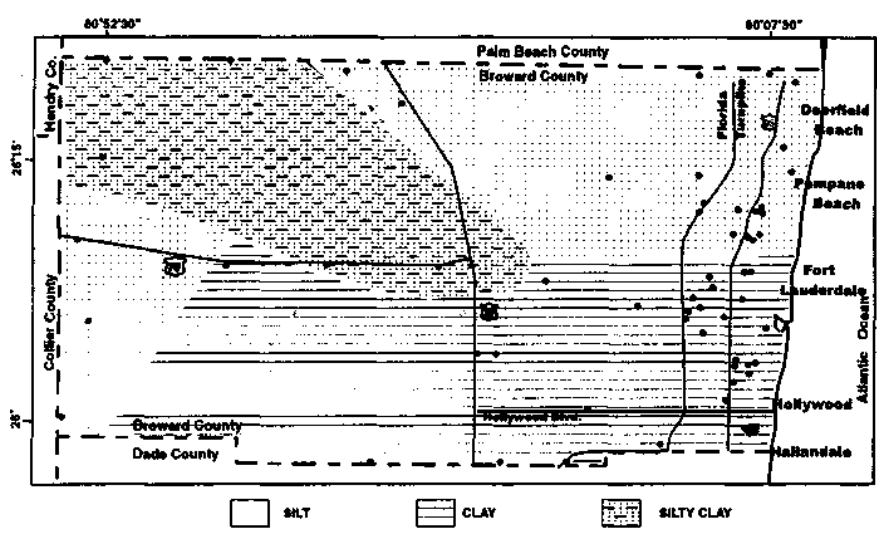

Figure 4 - Spatial distribution of sedimentary deposits comprising the lower Tamiami Formation in Broward County, Florida. Lithologic characteristics described in the core logs suggest deposition on a continental shelf environment during early Tamiamian time. Nearshore reefal deposits in the western part of the study area grade seaward to shelf sands.

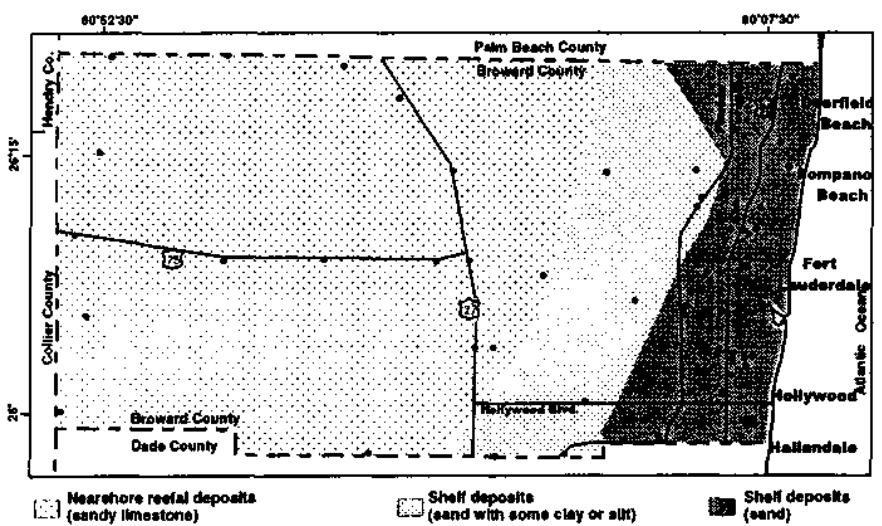

Figure 5 - Paleogeography of depositional environments during the Miocene-Pliocene (late Tamiamian time) in Broward County, Florida. The depositional pattern indicates strong dependence on preexisting paleobathymetry and sea-level change. In the western part of the study area, the barrier bar (island) protects a marine restricted or lagoonal environment that grades northwards into estuarine or freshwater shoals.

or below marine water levels. Also, the logs show greater influence of inshore/nearshore clastic deposition than environments in the west. The influence of dynamic coastal conditions are also present in the sandy limestone layers of the Tamiami Formation, snowing slight changes in quartz content, in granulometry, and in faunal content. The gradual changes in faunal content, sediment composition, and granulometry indicate that the thin sand layer at the upper part of some logs represents a bar or beach deposit, probably part of the Anastasia Formation. At the upper part of some logs, (e.g. G-2315, G-2312, G2317, and G-2319) there is a thick sequence ( $3 \mathrm{~m}$ ) of pale orange, wellcemented limestones or sandy limestones that show neomorphic and drusy cavity-filling calcite and gastropods, from the Fort Thompson Formation. The presence of cavity-filling calcite and weathered surfaces indicates that the nearshore deposits were eventually exposed to freshwater flow and subaerial erosive conditions. The presence of stratigraphic discontinuities throughout the sedimentary sequences makes it difficult to fully assess the geological evolution.

\section{Coastal paleoenvironments in eastern Broward The}

eastern part of the study area shows a greater degree of spatial lithologic variability, although the sedimentological characteristics are very similar within individual logs. The similarity of lithological materials throughout the logs, from bottom to top, makes it difficult to infer changes in depositional environments with time (see logs G-2351 and G-2325 in Figure 8). Identification of boundaries between formations may be possible only on the basis of biostratigraphic zonation using microfossils. In spite of the gross similarity of the deposits, it is possible

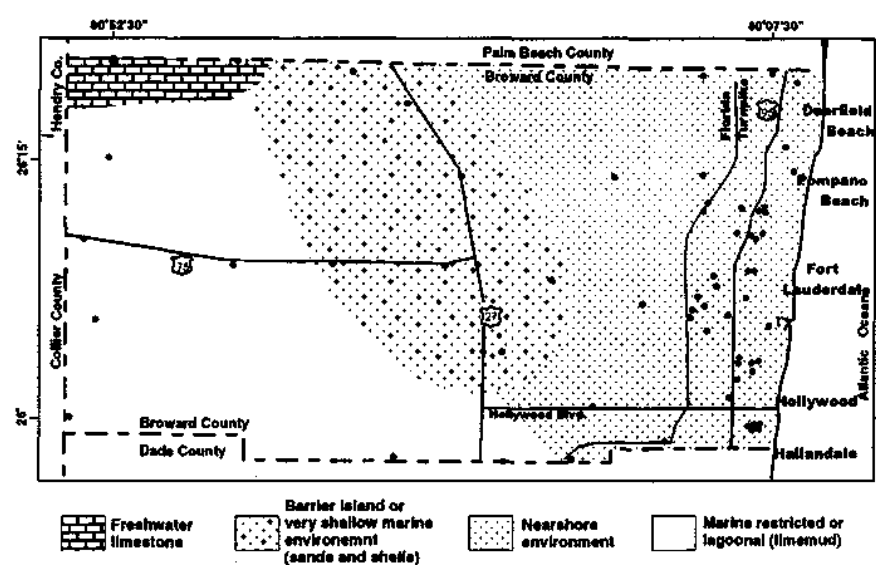

Figure 6 - Paleoenvironments during the early Pleistocene in Broward County, Florida. A sandy shoal (or barrier bar, island) is present along the central part of the county, restricting water circulation in western areas.

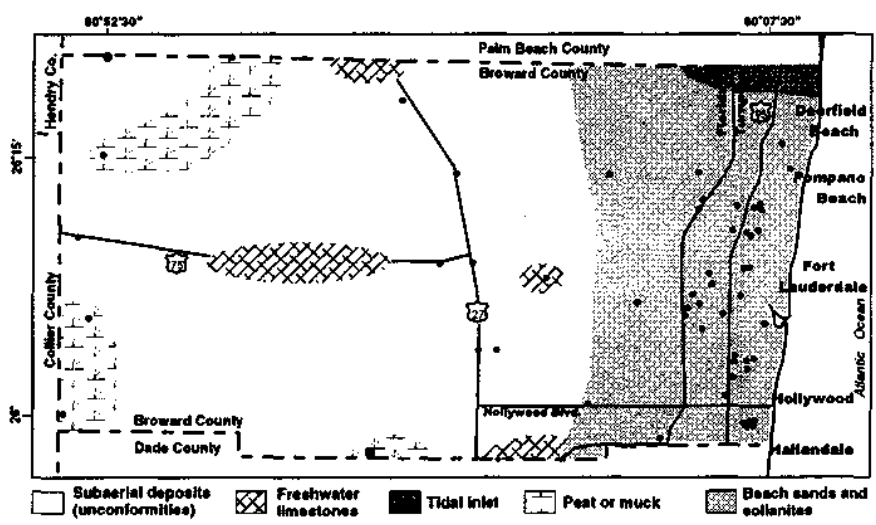

Figure 7. Paleodepositional environments during the late PleistoceneHolocene in Broward County, Florida. The paleogeography of the coastal area at this time consisted of a barrier bar or island with beach sands and eolianites; there was a tidal pass (paleoinlet) in the northeasternmost part of the region. In the western two-thirds of the study area, marine deposits are exposed to subaerial weathering processes or are covered by lacustrine deposits, peats, or mucks. The peats and mucks formed in an incipient wetland that is today referred to as the Florida Everglades. Most logs contain evidence of unconformities (subaerial weathering features) that hinder the elucidation of sequential paleoenvironments.

however to ascertain changes from marine conditions (clays, silts, and sands of the Tamiami Formation) to nearshore (Key Largo limestone, Anastasia, and Fort Thompson formations), and very shallow marine environments (oolitic facies in the Miami Limestone) and eolian materials in the upper part of the Pamlico sands. In the northeast part of the study area, logs G-2325 (Fig. 7), G-2323, and G-1228 represent the position of a pass or channel (paleoinlet) cut through a barrier bar. The section contains two 15-m thick sequences of coarse to very finegrained quartz sand (G-2325; 15-30 m, 60-75 m) interbedded with sandy (quartz) limestone layers. The whole sequence is about $65 \mathrm{~m}$ thick and the presence of sandy limestone layers may represent a situation similar to that described by Evans (1987) where there is oscillation of a shoal and channel system.

DISCUSSION Based primarily on fossil faunal assemblages seen in shell remains and the chemical properties of rocks, geologists have long recognized that the stratigraphic succession in southern Florida formed predominantly, with few exceptions, under a marine environment (e.g. Parker \& Cooke 1944, Parker et al. 1955, Hoffmeister 1974, Enos \& Perkins 1977). Exceptions are the lacustrine and swamp deposits of the Lake Okeechobee-Everglades depression that occurs partly in western Broward County. These deposits consist in freshwater beds of the Fort Thompson Formation, the freshwater Lake Flirt marl, and organic soils, mostly Everglades peats and mucks. According to Parker et al. (1955), the clays of southern Florida are usually greenish 
in color, calcareous in composition, with $10 \%-15 \%$ of phosphorite, and of marine origin containing a shallow-water fossil fauna indicative of warm subtropical conditions. Exceptions to these characteristics are the surficial red-colored lateiites occupying filled solution holes in karstified limestones in the "Redlands" area of Dade County.

In summary, the Neogene geological framework of Broward County consists of alternating fresh, brackish-water, and marine deposits laid down under generally shallow water conditions. Generally, fine-grained calcareous marine sediments comprise the lower sections of the logs, while the-upper sedimentary layers are formed under nearshore depositional sequences. The presence of fine-grained sediments (often micritic) at the base of most logs suggests deposition under low energy conditions, probably on what was then the outer continental shelf. Following, a drop in sea level resulted in changing depositional conditions from open marine to nearshore environments in central and west Broward. At the same time, the easternmost logs continue to present characteristics of continental shelf deposits. During mid-Tamiamian time, no subaerial deposits are recorded in the logs and sandy limestones and reefal fauna were broadly deposited. During the early Pleistocene, the type of depositional environments increases when subaerial deposits were laid down and intercalated with marine sediments, as reported by Lidz \& Shinn (1991) for the Florida reef tract. The nearshore sediments were deposited on top of offshore sands in the upper Tamiami Formation (e.g. logs G-2314, G-2346, and G2319 , in Figure 8). Freshwater deposits such as lime muds and cavity-filling neoformed calcite occur at the top of the nearshore deposits (containing shallow water mollusks, pellets, bryozoans, and echinoid fragments) as described by Causaras (1985) and Fish (1988). A large sand bar (or shoal) was also present in central Broward at this time and may have acted as a barrier to water circulation, resulting in brackish conditions in western Broward. Such conditions may have been favorable for the deposition of calcium carbonate that formed the lime mud layers in a restricted-circulation marine environment as described in log G-2346 (Fig. 8). Evidences of subaerial exposure in northwestern Broward are the presence of freshwater limestones (logs G2314 and G-2313) and younger cavity-filling calcite in some vughy deposits.

Fish (1988), discussing the complexity of depositional environments in eastern and central Broward County, pointed out that lithologies are variable in space and time, resulting in greater diversity between core logs there than in western Broward County where the continuity of lithologic sections is greater. This depositional pattern is evident in the cross-sections where there is greater similarity between logs in north-south cross-sections than in west-east cross-sections (see Figure 3). This shore-parallel pattern of freshwater limestones, lacustrine deposits, and subaerial crusts grading to beach sands and eolianites reflects the importance of shoreline variations and associated changes in water depth in defining the geologic framework in this area. The importance of shoreline position and sea-level changes in determining the distribution of detrital sediments and the depositional characteristics in south Florida was also observed by Lidz \& Shinn 1991.

Associated with increasing complexity in the Neogene is an increase in siliciclastic sedimentation. Limestones and sandy limestones are the dominant lithology but quartzose sands and sandstones become more important toward the base of the logs, toward the coast and near midsections of the county. This change in sediment supply, associated with the final disappearance of the Gulf Trough, allowed siliciclastic sediments to be transported to the Florida Platform as a result of broad uplift and erosion of the Appalachian Mountains in the late Paleocene (Scott 1993). The increase in granulometry toward the top of the logs and in logs closer to the coast resulted from sedimentary processes that changed from open marine (clastic deposition) to nearshore (dominance of sandy limestones) and subaerial deposits (freshwater limestones, peats and muck).

There are many difficulties that inhibit interpretations of paleodepositional environments in southeastern Florida. Perhaps the most important factor is the similarity of materials in the sedimentary layers. Some logs have very similar lithological characteristics throughout the section (e.g. logs G-2311, G-2313, G-2314, G-2317, G-2318) and it is thus difficult to recognize true boundaries between formations or know if specific deposits are contemporary or syndepositional in age. The similarity of materials leads to two different interpretations: (1) the sequence formed under the same kinds of environmental conditions or (2) the environmental conditions changed with time but produced similar kinds of deposits. A further complication is that the sedimentary record contains significant gaps in time as evidenced by numerous discontinuities. Missimer et al. (1994) estimated that about one-third of the time stratigraphic record is missing based on the time gaps across the major unconformities during Miocene and Pliocene in southeastern

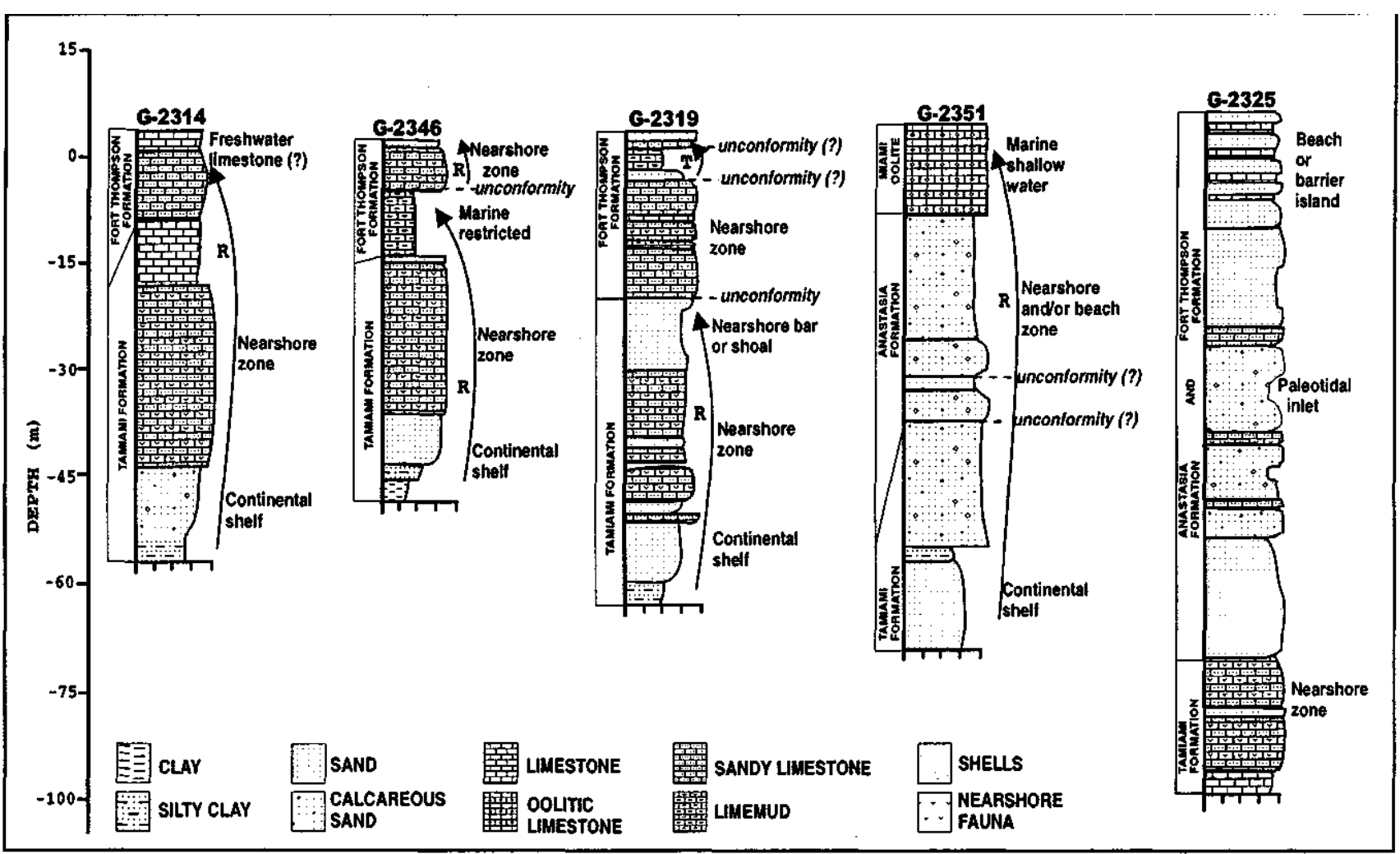

Figure 8 - Lithologic logs in diagrammatic section showing changes in paleoenvironments from the Miocene through the Pleistocene to the Holocene. Lags G-2314, G-2346, G-2319, G-2351, and G-2325 represent key paleoenvironmental sections in northwestern, southwestern, central, southeastern, and northeastern Broward County, Florida. Regressive sequences (R) are shown as general trends and do not necessarily depict only one glacio-eustatic event. Marine transgressions followed hiatuses when formations were subaerially exposed as groundsurfaces. 
Florida. The environmental transitions within the Pleistocene are numerous and complex due to erosive events, weathering of the landsurface, and dissolution of limestones that produced karstified landscapes. Evidence of Pleistocene sea-level oscillations in the southern Florida region consists of subsurface subaerial features such as laminated calcrete, peat, root, casts, and mold (Lidz \& Shinn, 1991). Recognition of these kinds of features suggest that most of Broward County was completely emerged during mid-late Pleistocene time. Beach sands and eolianites (Pamlico sand) dominated the eastern part of Broward County, while in western Broward peat or muck (wetlands formed by gradual shoaling) were formed. At this time, freshwater deposits became more frequent and widely spread along the central axis of Broward.

Anyway, it is essential to clarify the parameters used to differentiate the formations. Examples of the problematic similarity between sedimentary deposits are provided by attempts to separate the marine deposits of the Fort Thompson Formation from the upper Tamiami Formation (in central Broward County) and efforts to separate the interbedded layers of the Fort Thompson, Anastasia, and Key Largo formations in eastern Broward (e.g. Lovejoy 1987, Fish 1988, Missimer 1993, Scott 1993). In log G-2314, for example, the Fort Thompson sandy limestone is very similar to the Tamiami sandy limestone, the salient differences being formational color and faunal content. The Fort Thompson is yellowish-gray colored and contains mollusks whereas the Tamiami Formation is light olive-gray in color with a more diverse fauna that includes mollusks, corals, barnacles, bryozoans, and echinoid fragments. In some logs, sedimentary and stratigraphic differences are not easily detected, and biostratigraphic methods of dating seem to partly resolve the problem. For example, paleontologic data indicate that the Hawthorn Group and Tamiami Formation were formed in middle and late Miocene, respectively (Parker et al. 1955), while stable strontium isotopes, magnetostratigraphy, associated with biostratigraphy indicate that Hawthorn Group deposition began in late Oligocene $(30 \mathrm{Ma})$ and continued through early Pliocene time $(4.5 \mathrm{Ma})$ and that the Tamiami Formation formed during the Pliocene, between 4.5 and 2.8 Ma (Missimer et al. 1994).

As a result of these complicating factors, occurrences of specific may be shown by reference to the silts and clays present at the base of many logs. Parker et al. (1955) andCausaras (1985) demonstrated that the differentiation of clays and silts of the Tamiami from the Hawthorn formations was a very difficult task. These fine-grained materials were sometimes considered to be part of the Tamiami Formation rather than the Hawthorn Formation, as suggested by Causaras (1985) and Fish formations were not reported, omitted from descriptions, or defined in different ways from previous studies. One example of these difficulties

(1988). Based on prior recognition and extent of the problem, as reported in the literature, and considering that this uncertainty will not influence interpretations of depositional conditions, it was decided that the Hawthorn Formation should not be considered in this study. Although gathering of more complete and detailed descriptions of the formations was not the main goal of this study, interpretations of sedimentary environments would be simplified if formational boundaries and regional stratrigraphies were completely understood.

CONCLUSION In general terms, the geological framework of Broward County consists of marine deposits laid down under shallow water conditions. The lower part of the logs is commonly constituted by clays and silts deposited on a continental shelf, while the upper sedimentary layers were formed under nearshore depositional conditions. Changes in the sedimentary characteristics were caused mostly by variations in the water depth, sometimes resulting in the development of a nearshore reefal fauna and sometimes resulting in clastic deposition of quartzose sand.

This study represents an initial attempt to identify and relate late Cenozoic paleoenvironments through space and time in Broward County. One result of this effort culminated in the preparation of four maps (Figs. 4, 5, 6, 7) showing the changes in sediments distribution and interpreted paleoenvironments during the late Cenozoic (from Miocene to Pleistocene). Boundaries between environments and/or lithologic provinces were interpolated in areas with no borehole data (mainly in western Broward) and between contemporary deposits from one $\log$ to another due to difficulties associated with facies identification and differentiation of syndepositional materials. Thus, the areal extent of different sedimentary materials, and especially their boundaries as shown in plan view, should be regarded as preliminary results. The deployment of absolute dating methods would be a significant advancement in chronostratigraphy that would provide a better basis for defining stratigraphic boundaries when discontinuities are present.

Acknowledgments The borehole data collection and analysis phases were supported by Broward County Department of Natural Resources Protection (DNRP), Water Management Division, under Contract No. 3EQ00001127. The Coastal Education \& Research Foundation, Inc. is thanked for providing computer facilities and specialized software for completing the project. We gratefully acknowledge Jose Nestor Cardoso for his valuable help with the computer works. A word of special thanks goes to Fran Henderson, Broward Office of Environmental Services, and Roberto Sanchez (DNRP) for leads as to potential sources of well logs, logistic support, and encouragement.

\section{References}

Alien, J.R.L. (ed.). 1982. Sedimentary Structures: Their Character and Physical Basis. Volume 1. Amsterdam, Elsevier. 593 p. Causaras, C. R. 1985. Geology of the

Surficial Aquifer System, Broward County, Florida

U. S. Geological Survey, 167p. (Water-Resources Investigations Report 84-4068). Collinson, J.D. \& Thompson, D. B.I 989. Sedimentary Structures. London, Unwin Hyman. 207 p. Enos, P. \& Perkins, R.D. 1977. Quaternary Sedimentation in South Florida. Geological

Society of America (Memoir 147). Evans, C.C. 1987. The relationship between the

topography and internal structure of an

ooid sand complex: the upper Pleistocene Miami Limestone. In: Miami Geological Society, Symposium on South Florida Geology, Miami, Proceedings, 18-41. Fink1,

C.W., Jnr.; Krupa, S.; Giddings, J.B. 1995. Regional surface flows to tide and submarine groundwater discharges along the inner continental shelf of SE Florida. In: SEPM, $1^{\text {st }}$ Congress on Sedimentary Geology, Program and Abstracts, 1:54. Finkl,

C.W., Jnr. \& Esteves, L.S. 1997. A preliminary analysis of Neogene depositional environments in Broward County, Florida. Florida Scientist, 60:94-103. Fish, J. E.

1988. Hydrogealogy, Aquifer Characteristics, and Ground-Water Flow of the Surficial Aquifer System, Broward County, Florida. U.S. Geological Survey, 92p. (Water-Resources Investigations Report 87-4034). Friedman, G.M.; Sanders, J.E.; Kopaska-Merkel, D.C. 1992. Principles of Sedimentary Deposits: Stratigraphy and Sedimentology. New York, Macmillan. 717 p. Halley,

R.B. \& Rose, P.R. 1977. Significance of fresh-water limestones in marine carbonate successions of Pleistocene and Cretaceous age, Dallas, Texas Bureau of Economic Geology (Report of Investigations No. 89)

Hoffmeister, J.E. 1974. Land From the Sea. Coral Gables, University of Miami Press, FL.

Jones, D.S.; Mueller, P.A.; Hodell, D.A.; Stanley, L.A. 1993. ${ }^{87} \mathrm{Sr} /{ }^{86} \mathrm{Sr}$ geochronology of Oligocene and Miocene marine strata in Florida. In: Miami Geological Society, Symposium on South Florida Geology, Miami, Proceedings, 15-26. Krumbein,

W.C. \& Sloss, L.L. 1963. Stratigraphy and Sedimentation. San Francisco, Freeman, 660 p. Krupa, S.; Finkl, C.W., Jnr.; Giddings, J.B. 1995. Application of geophysical signatures,

water quality, and sediment chemistry to paleo-sealevel studies in SE Florida. In: SEPM, $1^{\text {st }}$ Congress on Sedimentary Geology, Program and Abstracts, 1:78.
Lidz, B.H. \& Shinn, E.A. 1991. Paleoshorelines, reefs, and a rising sea: South Florida, U.S.A... Journal of Coastal Research, 7(1):203-230. Lovejoy, D.W. 1987. The Anastasia Formation in Palm Beach and Martin counties, Florida. In: Miami Geological Society, Symposium on South Florida Geology, Proceedings, 58-72. Missimer, T.M. 1993. Pliocene stratigraphy of southern Florida:

unresolved issues of

facies correlation in time. Miami, Florida Geological Survey, p. 33-42. (Special Publication 37). Missimer, T.M.; McNeill, D.F.; Ginsburg, R.N.; Mueller, P.A.; Covington, J.M.; Scott,

T.M. 1994. Cenozoic record of global sea level events in the Hawthorn Group and Tamiami Formation on the Florida Platform. Geological Society of America Abstract with Programs, 26:151. Parker, G. G. \& Cooke, C.W. 1944. Late Cenozoic resources of southeastern Florida, with

Parker, G. G.; Ferguson, G. E.; Love, S. K. 1955. Water Resources of Southeastern Florida with Special Reference to the Geology and Ground Water of the Miami Area. U. S. Geological Survey, 965p. (Water-Supply Paper 1255). Peck, D.M.; Missimer,

T.M.; Wise, S.W. 1976. Glacial-eustatic control of an upper Miocene transgressive-regressive sequence in a low latitude (southeastern U.S.) coastal plain. Geological Society of America Abstracts with Programs, 8(6): 1044-1045. Scott, T.M. 1993. Neogene stratigraphy of the Florida Peninsulaproblems and prospects.

Miami, Florida Geological Survey, 12p. (Special Publication No. 37). Sweeting, M.M. 1973. Karst Landforms. New York, Columbia University Press. Webb, S.D.; Wise,

S.W.; Wright, R. 1978. Late Miocene glacio-eustatic cycles in Florida; marine and fluvio-estuarine sequences. Geological Society of America Abstracts with Programs, 10(7):513. a discussion of the ground water. Miami, Florida Geological Survey (Bulletin 27). 